\title{
PENGEMBANGAN OBJEK WISATA BUDAYA : TAMAN PRASEJARAH LEANG-LEANG, MAROS, SULAWESI SELATAN
}

\author{
Enny Mulyantari \\ NIDN. \\ Dosen Sekolah Tinggi Pariwisata AMPTA Yogyakarta \\ Email : ennymulyantari@yahoo.co.id
}

\begin{abstract}
In the current era of globalization, the tourism sector has become one of the largest and strongest industries in the world, as well as the largest contributor to public and state revenues. Tourism has become part of the lives of people starting from the existing community in the city to the community in the village. Maros Regency in South Sulawesi has a lot of tourist attractions but the community has not been fully able to identify the tourism potential that exists in the region. This study aims to promote the potential, important values and strategies for the management and development of the Leang-leang Prehistoric Park as a tourist destination. The research result shows that Leang-Leang Prehistoric Park has a cultural tourist attraction containing commercial values that attract many tourists, with the assurance that the expenditure, time and cost, is worth for the experience obtained during the visit.
\end{abstract}

Keywords: important value, tourist object, development, cultural heritage

\section{PENDAHULUAN}

Pariwisata adalah suatu rangkaian aktivitas yang dapat dipahami dari berbagai pendekatan dan keberadaannya tidak terlepas dari kehidupan manusia (Ismayanti, 2010). Dalam Undang-Undang RI nomor 10 Tahun 2009 tentang Kepariwisataan dijelaskan antara lain, kepariwisataan adalah keseluruh-an kegiatan yang terkait dengan pariwisata dan bersifat multidimensi dan multidisiplin yang muncul sebagai wujud kebutuhan setiap orang dan negara serta interaksi antara wisatawan, masyarakat setempat, sesama wisatawan, pemerintah, daerah, dan pengusaha.

Sementara itu di dalam UndangUndang RI Nomor 11 tahun 2010 tentang Cagar Budaya khususnya pasal 85 dinyatakan Pemerintah, Pemerintah Daerah dan setiap orang dapat memanfaatkan Cagar Budaya untuk kepentingan agama,sosial, pendidikan, ilmu pengetahuan, kebudayaan dan teknologi,dan pariwisata. Kedua produk hukum negara yang berupa undang-undang diatas, merupakan pegangan dalam upaya pengembangan warisan budaya Taman Prasejarah Leang-leang.

Pentingnya warisan budaya perlu dikembangkan sebagai objek wisata budaya agar memiliki manfaat ganda yang diharapkan mampu meningkatkan devisa negara. Karena keberadaan warisan budaya sudah diatur dalam UU Cagar Budaya No. 11 tahun 2010, maka upaya pengembangan objek wisata harus mengikuti aturan tersebut. Dalam konsep pengembangan 
warisan budaya terdapat prinsip pelestarian yang tidak dapat diabaikan antara lain karena sifat warisan budaya tidak dapat terbaharui (non renewable), tidak dapat dipindahkan (non movable), terbatas jumlahnya, dan rapuh (fragile vulnerable). Dengan demikian dalam mengembangkan diperlukan kehati-hatian, karena dikhawatirkan ada unsur mengubah atau memperbaharui (Sulistyanto, 2008).

Lebih lanjut pada pasal 78 UndangUndang No 11 tahun 2010 tentang Cagar Budaya dijelaskan bahwa, "Pengembangan Cagar Budaya dilakukan dengan memperhatikan prinsip pemanfaatan, keamanan, keterawatan, keaslian, nilai-nilai yang terkandung di dalamnya". Pada prinsipnya pasal tersebut menegaskan, bahwa upaya pengembangan harus menerapkan konsep berwawasan pelestarian.

Sementara itu Yoeti (2008) menegaskan program pemerintah berkeinginan untuk mengembangkan pariwisata sebagai suatu industri dengan tujuan untuk mempercepat proses kesempatan berusaha, kesempatan bekerja, peningkatan pemerataan pendapatan masyarakat, terutama bagi mereka yang berusaha dalam industri pariwisata. Ada beberapa komponen ekonomi pariwisata yang mempengaruhi pendapatan nasional antara lain pengeluaran wisatawan nusantara dan pengeluaran wisatawan mancanegara, investasi dari pemerintah atau swasta di sektor pariwisata, pengeluaran promosi pariwisata, dan pengeluaran usaha bidang pariwisata (Hermawan, 2012).

Pada dasarnya uraian di atas ingin menjelaskan, bahwa peranan sektor pariwisata penting dikembangkan dalam upaya pertumbuhan ekonomi guna mencapai kesejahteraan masyarakat.
Namun demikian pembanguanan pariwisata tidak dapat berdiri sendiri, tetapi perlu bekerjasama dengan berbagai pihak termasuk di dalamnya pemerintah, pemangku kepentingan, dan masyarakat. Dalam upaya mempertahankan kualitas yang ditawarkan dengan dasar Rencana Pembangunan Jangka Menengah Nasional Tahun 2015-2019, merupakan strategi pembangunan nasional. Dalam strategi pembangunan nasional ini, salah satu proritasnya adalah membangun sektor unggulan, termasuk didalamnya sektor pariwisata. Rencana tersebut harus didukung oleh kebijakan pembangunan pariwisata sesuai arah Kebijakan Rencana Induk Pembangunan Pariwisata Nasional (Ripparnas) 2010-2015 yaitu dengan pengembangan destinasi wisata, pemasaran pariwisata, industri pariwisata, dan kelembagaan pariwisata (Teguh dan Avenzora, 2013).

Kawasan Maros Sulawesi Selatan merupakan salah satu wilayah yang kaya akan daya tarik wisata baik wisata alam, wisata sejarah, maupun wisata budaya. Berdasarkan penelitian arkeologi ada sekitar 57 situs gua di wilayah Maros yang dapat dikembangkan sebagai destinasi wisata. Dari sekian banyak daya tarik wisata tersebut, terdapat salah satu daya tarik wisata sejarah yang banyak dikunjungi wisatawan yaitu Taman Prasejarah Leangleang di Kabupaten Maros. Objek wisata ini berada di dalam wilayah Taman Nasional Bantimurung, dalam jajaran pegunungan karst yang sudah berumur ribuan tahun dan diakui sebagai kawasan karst terbesar kedua di dunia setelah Guangzhou di China (Fadlan dkk, 2012).

Sebagai objek wisata, kawasan Taman Prasejarah Leang-leang terdapat tiga buah gua yang sudah dibuka dan 
dikembangkan sebagai objek wisata yaitu Gua Sumpang Bita dan Leang-leang yang terdapat di dalam kawasan TNBB dan Gua Biringere yang terdapat di luar kawasan karena terletak dekat dengan lokasi pabrik semen di Kabupaten Pangkep (BP3, 2011). Di dalam gua tersebut terdapat tinggalan arkeologis berupa lukisan cap telapak tangan, alat batu, dan sampah dapur. Gua kedua Leang Burung 2 terdapat tinggalan berupa lukisan cap telapak tangan, sedangkan gua ketiga adalah gua Leang Pangngie di bagian dinding tertera cap telapak tangan berwarna merah, gambar babi. Gua-gua ini merupakan bukti sejarah adanya kehidupan manusia masa lalu yang menggunakan gua sebagai sarana untuk hunian, dan saat ini sudah dibuka untuk umum sebagai objek tujuan wisata. Pengunjung di Taman Prasejarah Leangleang berasal dari berbagai kalangan, yaitu terdiri atas pengunjung umum, asing, dinas, maupun dari kalangan pelajar/mahasiswa dan ilmuwan.

Taman Prasejarah Leang-leang secara administratif termasuk dalam wilayah Desa Leang-leang, Kelurahan Kalabbirang yang berada di wilayah Kecamatan Bantimurung, Kabupaten Maros, Propinsi Sulawesi Selatan. Terletak $34.9 \mathrm{~km}$ sebelah utara Kota Makassar. Kawasan ini dapat dicapai dalam waktu \pm 1,5 jam dengan menggunakan kendaraan roda dua maupun roda empat. Dari kota Makassar melalui jalan poros Bone pada kilometer 34.9 belok kiri menyusuri jalan desa ke arah utara sampai ke kaki perbukitan karst (BP3, 2011).

Pembangunan dan pengembangan Taman Prasejarah Leang-leang sebagai objek wisata sejarah dan budaya berdampak semakin banyaknya pengunjung yang datang dan fenomena ini diperlukannya sarana dan prasarana yang lebih lengkap untuk menunjang keberhasilannya sebagai destinasi wisata. Namun, mampukah kawasan tersebut menyesuaikan diri agar pelestarian dan konservasi lingkungan/sumber daya alam, khususnya potensi sejarah dan budaya berjalan seiring dengan pengembangan kegiatan pariwisata. Upaya pengembangan pariwisata memerlukan kerja keras disamping strategi yang tepat sesuai dengan kondisi lingkungan.

Pengamatan yang mendalam terhadap objek wisata ini, memang memiliki berbagai potensi alam dan budaya yang dapat dikembangkan sebagai destinasi wisata. Namun, masyarakat belum mampu mengidentifikasi permasalahan-permasalahan yang ada di wilayah tersebut. Berdasarkan uraian pada latar belakang di atas, masalah yang ingin diteliti dalam makalah ini dapat dirumuskan sebagai berikut.

1. Potensi-potensi apakah yang ada yang ada di Taman Prasejarah Leangleang?

2. Nilai penting apa saja yang terkandung dalam obyek wisaya tersebut?

3. Bagaimana strategi pengembangan DTW Taman Prasejarah Leang-leang ke depan?

Dengan demikian tujuan yang ingin dicapai dalam penelitian ini secara khusus adalah mengidentifikasi potensi-potensi yang ada di lingkungan Taman Prasejarah Leang-leang dan mengungkapkan nilai penting serta menjabarkan strategi yang paling sesuai dalam pengelolaan Taman Prasejarah Leang-leang sebagai destinasi wisata yang berbasis kerakyatan. 


\section{LITERATURE RIVIEW \\ Pengembangan}

Pengertian pengembangan dijelaskan oleh Winardi (2013) yaitu proses, cara, perbuatan menjadikan maju atau pembangunan secara bertahap, teratur dan berkelanjuntan, yang menjurus ke sasaran yang dikehendaki. Pengembangan juga dapat dinilai sebagai respon terhadap perubahan yang selalu terjadi dari waktu ke waktu. Didalam mengupayakan pengembangan, perencanaan yang baik menjadi tindakan yang mutlak dilakukan.

Pengertian yang sama dikemukakan oleh Siregar dalam Listyorini (2015) bahwa pengembangan adalah suatu usaha menuju ke arah yang lebih baik, yang berarti adanya perubahan dan pertumbuhan. Perubahan dalam hal ini bisa berarti kualitas maupun kuantitas.

\section{Objek Wisata}

Istilah objek wisata dan atraksi wisata sering pula disebut dengan daya tarik wisata, di dalam Undang-Undang RI nomor 10 Tahun 2009 tentang Kepariwisataan dijelas-kan daya tarik wisata yaitu segala sesuatu yang memiliki keunikan, keindahan, dan nilai yang berupa keanekaragaman kekayaan alam, budaya, dan hasil buatan manusia yang menjadi sasaran atau tujuan kunjungan wisatawan. Objek Wisata atau daya tarik wisata menurut Ismayanti (2010) dibedakan beberapa jenis daya tarik wisata yang dikenal dewasa ini adalah sebagai berikut.

\section{Daya Tarik Wisata Alam}

Daya tarik wisata alam merupakan segala sesuatu yang berhubungan dengan alam, yaitu berupa alam yang terbentuk karena hasil ciptaan Tuhan, seperti pantai, gunung, air. Tata lingkungan yang alami, misalnya danau dan tata lingkungan hasil budidaya manusia, seperti perkebunan dan peternakan.

\section{Daya Tarik Wisata Budaya}

Daya tarik wisata budaya merupakan daya tarik wisata yang berdasarkan pada mosaik tempat, tradisi, kesenian, upacaraupacara, dan pengalaman memotret suatu bangsa atau suku bangsa dengan masyarakat, yang merefleksikan keanekaragaman (diversity) dan identitas (karakter) dari masyarakat atau bangsa bersangkutan. Daya tarik wisata budaya menonjolkan sebuah daya tarik sebagai berikut.

a. Situs arkeologi, sejarah dan budaya, seperti monument, gedung bersejarah, rumah ibadah, daerah atau kota bersejarah, situs purbakala, museum.

b. Pola kehidupan masyarakat, daya tarik wisata budaya yang berbentuk adat istiadat, busana, upacara keagamaan, tradisi, gaya hidup.

c. Seni dan kerajinan tangan baik berwujud atau tak berwujud, seperti tari, music, drama, patung, arsitektur.

d. Kegiatan ekonomi masyarakat berupa nelayan, kehidupan petani.

e. Festival budaya baik yang rutin setiap bulan atau kegiatan tahunan dalam masyarakat, seperti upacara panen padi, festival laying-layang.

\section{Daya Tarik Wisata Minat Khusus}

Daya tarik wisata minat khusus merupakan wisata yang menawarkan kegiatan yang tidak bisa dilakukan oleh wisatawan pada umumnya atau wisata dengan keahlian khusus atau ketertarikan khusus. Daya tarik wisata minat khusus ini memanfaatkan alam dan budaya sebagai latar belakang, namun kegiatannya 
diciptakan dengan tantangan dan perhatian spesifik.

Taman Prasejarah Leang-leang merupakan objek wisata yang memiliki keunikan baik wisata alam maupun budaya yang langka keberadaannya. Objek wisata ini, sangat potensial untuk dikembangkan sebagai daya tarik wisata alam dan budaya, disamping sebagai wahana penelitian, pendidikan, dan pengembangan ilmu pengetahuan. Agar objek dan daya tarik wisata alam tersebut dapat dimanfaatkan secara nyata, diperlukan arahan dan pedoman yang bersifat komprehensif dalam pengembangannya.

\section{METODE PENELITIAN}

Jenis penelitian yang digunakan adalah deskriptif kualitatif, dengan harapan dapat menemukan dan memahami fenomena yang akan diteliti pada suatu periode tertentu. Pengertian diatas memperlihatkan beberapa kata kunci, yaitu adanya proses, pemahaman, kompleksitas, dan interaksi dengan masya-rakat. Penelitian ini menggunakan data primer dan data sekunder. Data primer dicari melalui tiga cara yaitu observasi, wawancara, dan diskusi terfokus (Focus Group discussion). Hasil dari observasi lapangan, dipertajam melalui wawancara mendalam dilakukan terhadap beberapa informan yang dipandang mengetahui permasalahan yang diteliti. Instumen dari metode ini adalah peneliti itu sendiri, sehingga peneliti harus memiliki bekal teori dan wawasan luas, mampu bertanya, menganalisis dan mengkonsrtruksikan objek yang diteliti menjadi lebih jelas dan memiliki makna (Sugiyono, 2012).

Dalam rangka mewujudkan pengembangan wisata budaya secara lestari di kawasan Taman Prasejarah Leang-leang, diperlukan upaya strategis yang terprogram dan terstruktur. Untuk itulah kemudian diperlukan adanya rencana pengembangan pariwisata sebagai pedoman dan arahan dalam pengembangan pariwisata budaya di kawasan Taman Prasejarah Leang-leang dengan mengunakan teknik analisis SWOT (Strength, Weaknesses, Opportunities, Threats). Analisis ini pada hakekatnya menjabarkan secara rinci faktor internal kekuatan (Strength) dan kelemahan (Weaknes) serta faktor eksternal berupa peluang (Opportunity) dan ancaman (Threat). Dengan analisis sebagaimana disinggung di atas, diharapkan dapat diperoleh kesimpulan yang akurat dalam penelitian ini. Yaitu dapat menjawab rumusan permasalahan dan pertanyaan penelitian, tentang potensi pariwisata dan strategi pengembangannya di lokasi objek wisata budaya Taman Prasejarah Leangleang.

\section{HASIL DAN PEMBAHASAN}

Kompleks Gua Leang-leang di Kabupaten Maros merupakan salah satu objek wisata sejarah terpenting diantara beberapa kompleks gua prasejarah di Sulawesi Selatan. Para sarjana sepakat menyebut peninggalan gua prasejarah di Sulawesi Selatan sebagai peninggalan budaya Toala (Nur, 2009). Data lapangan memperlihatkan bahwa dari 40 situs gua yang ada, hanya dua gua yaitu Leang Pattae dan Leang Petta Kerre yang berada di Taman Purbakala Leang-leang yang telah dimanfaatkan untuk objek wisata, sementara 38 gua yang lain selama ini hanya dimanfaatkan untuk kebutuhan penelitian ilmiah.

Dalam perspektif budaya minimal terdapat empat nilai penting yang 
terkandung dalam Taman Prasejarah Leang-leang.

Pertama Nilai Penting Sejarah, yaitu apabila sumber daya budaya tersebut dapat menjadi bukti yang berbobot dari peristiwa yang terjadi pada masa prasejarah dan sejarah, berkaitan erat dengan tokoh-tokoh sejarah, atau menjadi bukti perkembangan penting dalam bidang tertentu. Nilai penting sejarah yang dikandung oleh Kompleks Gua Leang-leang adalah adanya dua jenis budaya yang pernah berkembang yaitu budaya pra Austronesia dan budaya Austronesia. Kedua jenis budaya tersebut biasa disebut oleh prasejarawan sebagai budaya Toala yang berkembang pada masa plestosen sekitar 31.000-19.000 BC, komplek gua ini telah dihuni oleh manusia pra Austronesia. Sementara data lukisan di dinding gua di Leang-leang adalah salah satu bukti ekspresi seni lukis tertua di Asia Tenggara.

Kedua nilai Penting Ilmu Pengetahuan, apabila sumber daya budaya itu mempunyai potensi untuk diteliti lebih lanjut dalam rangka menjawab masalahmasalah dalam bidang keilmuan tertentu. Nilai penting ilmu pengetahuan yang terkandung di Kompleks Gua Leang-leang adalah ilmu arkeologi, geologi, ekologi, biologi dan speleogenesis. Dianggap memiliki nilai penting arkeologi karena Kompleks Gua Leang-leang mengandung data arkeologi yang padat. Jumlah 57 gua dengan variasi temuan yang tinggi di setiap gua adalah kekayaan luar biasa. Kekayaan ekologi Kompleks Gua Leang-leang yang merupakan bagian dari kawasan karst Bantimurung-Bulusaraung menjadi alasan kuat penetapan kawasan tersebut menjadi kawasan Taman Nasional. Kompleks Gua Leang-leang memiliki nilai penting ilmu speleogenesis karena banyaknya gua aktif atau gua yang masih dalam. Kompleks Gua Leang-leang memiliki nilai penting biologi karena memiliki kekayaan flora dan fauna yang prospektif untuk penelitian biologi di masa mendatang.

Ketiga Nilai Penting Kebudayaan, nilai penting kebudayaan yang dikandung oleh Kompleks Gua Leang-leang dapat dibagi menjadi dua jenis yaitu nilai etnik, dan nilai estetik. Kompleks Gua Leangleang memiliki nilai penting etnik karena ditemukan bukti keberadaan komunitas Austronesia (ras Mongoloid) pada masa prasejarah di Sulawesi Selatan. Bukti arkeologis tersebut merupakan salah satu bukti tertua tentang genealogi dan budaya, menjadi jati diri (cultural identity) dari Etnik Bugis, Makassar, dan Toraja yang mendiami Sulawesi Selatan sekarang. Kompleks Gua Leang-leang diasumsikan memiliki nilai penting estetik karena ditemukan banyak lukisan dinding gua, berdasarkan tinggalan artefaktualnya bisa dikategorikan sebagai hasil pencapaian budaya yang sangat tinggi, karena pada masa prasejarah masyarakat Sulawesi Selatan sudah mengenal komuniksai verbal sebagaimana diperlihatkan oleh berbagai lukisan purba di dinding-dinding gua. Tahun 2014, Maxime Aubert dari Universitas Wollongong, Australia dan tim melakukan penelitian di Leang Timpuseng. Penelitian ini menjadi perhatian dunia arkeologi internasional karena berkesimpulan pertanggalan lukisan dinding gua sekitar 40.000 tahun yang lalu, setara dengan lukisan tertua di Eropa. Metode pertanggalan yang digunakan merupakan metode baru, yaitu uranium series dating di speleothems (deposit) gua (Aubert et al. 2014).

\section{Keempat Nilai Penting}

Kepariwisaan, dengan pengertian bahwa 
nilai sumber daya tersebut mampu menjadi daya tarik wisatawan untuk berdatangan, dan berdampak pada peningkatan kesejahteraan masyarakat, maka tidak perlu diragukan lagi peranan warisan budaya dalam kepari-wisataan sangat besar. Keberadaan objek wisata Taman Prasejarah Leang-leang secara tidak langsung membawa dampak terhadap perekonomian warga sekitar objek wisata tersebut. Hal ini tampak dari mulai munculnya berbagai jenis-jenis usaha sampingan dari warga seperti pedagang suvenir, pedagang asongan, pedagang makanan dan minuman, penginapan, dsb. Jika semula pekerjaan utama warga sekitar objek wisata hanya sebagai petani, pegawai, dan sebagainya, maka dengan keberadaan objek wisata ini mampu membuka lapangan usaha baru yang bisa dilakukan di waktu senggang.

Sebagaimana diungkapkan di depan, upaya pemecahan masalah pengembangan Taman Prasejarah Leang-leang mempergunakan analisis SWOT, dengan memadukan antara faktor-faktor internal yakni strength (kekuatan-kekuatan) dan Weaknesses (kelemahan-kelemahan), dengan faktor-faktor eksternal yakni Opportunities (peluang-peluang) dan Treaths (kendala atau ancaman).

\section{Kekuatan (Strength)}

Sebagai wilayah pengembangan pariwisata, Taman Prasejarah Leang-leang memiliki kekuatan-kekuatan (strengths) yang dapat dijadikan modal pengembangan wilayah ini. Berdasarkan hasil pengolahan data di lapangan, nampak beberapa kekuatan-kekuatan yang dimiliki wilayah ini diantaranya:

\section{a. Potensi sumber daya alam}

Potensi sumber daya alam yang dimiliki taman prasejarah ini cukup mengesankan. Wilayah ini sudah berumur ribuan tahun dan diakui sebagai kawasan karst terbesar kedua di dunia setelah Guangzhou di China. Taman Prasejarah Leang-leang merupakan pegunungan karst yang sudah berumur ribuan tahun dan yang menakjubkan memiliki 286 gua 57 situs gua diantaranya berada di Taman Prasejarah Leang-leang.

\section{b. Adanya potensi sumber daya budaya}

Kompleks Leang-leang Maros ini sangat menarik, karena goa ini dulunya sebagai tempat tinggal manusia yang terkenal dengan sebutan budaya Toala, sekaligus di gua ini tersimpan berbagai lukisan tertua di dunia, sehingga situs purbakala ini penting sebagai media edukatif kultural.Terdapat kurang lebih 27 lukisan telapak tangan dengan berbagai posisi, lukisan perahu, hewan, figur manusia, simbol ekspresi diri melalui bahasa gambar atau bahasa rupa pada masa prasejarah.

\section{c. Adanya dukungan sumber daya manusia dan dukungan masyarakat}

Kemampuan sumber daya manusia khususnya untuk kepentingan pariwisata, ternyata cukup mendukung. Hal ini terbukti dari cukup banyaknya warga masyarakat yang telah berkecimpung pada sektor pariwisata. Salah satu pilar pariwisata dalam konsep stakes holders pariwisata yakni masyarakat lokal (host) sudah terpenuhi. Demikian pula dukungan dari pemerintah melalui eksistensi kementerian Kehutanan, Direktorat Jenderal PHKA, Balai Taman Nasional Bantimurung Bulusaraung, serta perangkat yang ada dibawahnya.

\section{d. Lokasi strategis}

Lokasi DTW yang ada dikawasan taman prasejarah ini secara geografis sangat 
strategis dan aksesibilitas yang mudah dari kota Makassar, Maros, Bone, dan Bandara Udara Internasional Hasanuddin yakni tersedianya berbagai amenitas pariwisata. Berbagai amenitas untuk mendukung kegiatan pariwisata telah tersedia di wilayah ini.

\section{Kelemahan (Weakness)}

Di samping adanya kekuatankekuatan yang dimiliki, Wilayah Taman Prasejarah Leang-leang memiliki berbagai sisi kelemahan. Kelemahan-kelemahan ini merupakan faktor internal yang ada di wilayah tersebut. Berdasarkan hasil dari pengolahan data yang telah dikumpulkan di lapangan, maka dapat digambarkan kelemahan-kelemahannya adalah sebagai berikut.

\section{a. Atraksi wisata belum mampu menjadi daya tarik tersendiri bagi wisatawan}

Objek wisata akan sangat diminati oleh wisatawan jika daerah tersebut mampu menawarkan atraksi wisata yang unik dan menarik. Atraksi wisata yang unik dan menarik serta tidak ada duanya di tempat lain, sehingga wisatawan merasakan masih sama dengan daerah wisata lainnya

\section{b. Lemahnya sarana prasarana}

Tiadanya sarana transportasi umum menuju kawasan Taman Prasejarah Leangleang menyebabkan sulitnya wisatawan yang ingin datang berkunjung jika tidak membawa kendaraan pribadi. Di samping itu kurang terpeliharanya fasilitas toilet. Fasilitas seperti toilet harusnya lebih diperhatikan lagi tingkat kebersihannya. Aksesibilitas menuju ke arah situs-situs gua prasejarah merupakan faktor pendukung bagi pembangunan objek dan daya tarik wisata melalui warisan budaya bangsa. Untuk mencapai gua dari jalan besar memang sudah cukup memadai, namun untuk mencapai gua memang sulit walaupun sudah dibuat tangga yang cukup tinggi.

\section{c. Belum adanya kerjasama dengan pihak luar.}

Kerjasama dengan pihak lain dalam hal pariwisata khususnya dengan Biro Perjalanan Wisata atau travel agen perlu dilakukan, sehingga berbagai potensi wisata yang dimiliki akan diketahui oleh masyarakat.

\section{d. Kurangnya Tenaga Kerja Profesional}

Minimnya tenaga profesional dalam pengelolaan daya tarik wisata menyebabkan berbagai kendala kurang dapat diatasi. Fakta ini dapat dipahami, karena tenaga profesional khususnya di bidang pelestarian warisan budaya yang menyangkut masalah teknis arkeologi cukup langka di Indonesia.

\section{Peluang (Opportunity) Pengembangan} Taman Prasejarah Leang-leang

Dalam penyusunan strategi pengembangan objek wisata, disamping mempertimbangkan faktor-faktor internal, juga harus menggunakan faktor-faktor eksternal. Salah satu dan faktor ini adalah merupakan peluang-peluang ekternal sebagai berikut.

\section{a. Kebijakan pemerintah}

Adanya kebijakan pemerintah Kabupaten Maros dalam pengembangan DTW yang mampu membuktikan bahwa objek wisata ini layak untuk dikembangkan serta memiliki peluang untuk berkembang.

b. Situs Leang-Leang sudah terkenal

Kemasyuran Situs Leang-leang sudah terkenal di dunia karena langkanya jenis situs seperti ini sebagaimana diperlihatkan oleh lukisan di dinding gua-gua prajejarah yang langka keberadaannya di Indonesia. 


\section{c. Dekat dengan lokasi pariwisata lainnya}

Objek wisata ini dekat dengan Kawasan Taman Nasional Bantimurung Bulusaraung, sehingga wisatawan dapat sekali pergi dalam berwisata.

\section{d. Adanya komitmen}

Komitmen para penentu kebijakan di tingkat nasional dan regional terhadap pelestarian sumber daya budaya, alam, dan lingkungan.

e. Adanya peran serta masyarakat dalam pelestarian budaya

Kesadaran masyarakat khususnya masyarakat lokal yang ada di sekitar dalam melestarikan budaya mereka turut menjadi peluang positif dalam pengembangan pariwisata ini ke depan.

\section{f. Pesatnya teknologi informasi}

Pesatnya perkembangan ilmu pengetahuan dan teknologi sekarang ini telah berimplikasi pada pengembangan suatu destinasi wisata Taman Prasejarah Leang-leang.

Hambatan/ancaman (Threat) Pengembangan Taman Prasejarah Leang-leang

Selain adanya peluang-peluang yang merupakan faktor eksternal, pengembangan pariwisata harus mampu mengidentifikasikan hambatan-hambatannya. Berdasarkan hasil observasi serta pengolahan data di lapangan menunjukkan adanya hambatanhambatan/ ancaman dalam pengembangannya sebagai berikut.

a. Masih Adanya Penebangan Liar

Masih tingginya tingkat kerawanan kawasan, baik dari aktifitas penebangan liar dan perdagangan kayu illegal, perambahan kawasan, kebakaran hutan dan kegiatan pertambangan tanpa izin. b. Rendahnya tingkat pendidikan

Masih rendahnya tingkat pendidikan masyarakat di sekitar kawasan Taman Prasejarah Leang-leang secara tidak langsung mempengaruhi mutu kualitas sumber daya manusia.

\section{c. Ketergantungan pada sumber daya} alam yang tinggi

Kondisi perekonomian masyarakat yang masih sangat bergantung pada ketersediaan sumber daya alam di dalam kawasan Taman Prasejarah Leang-leang.

\section{d. Tidak menarik Investor}

Kebijakan investasi di dalam kawasan konservasi ini tidak menarik bagi para investor. Pengembangan pariwisata membutuhkan peran serta investor untuk ikut serta mengembangkan pariwisata (Siagian 2008). Keberadaan investor sangat penting untuk diadakan karena memberikan dampak langsung bagi pengembangan kepariwi-sataan. Salah satu cara yang dapat dilakukan dengan memberikan informasi yang akurat kepada investor mengenai potensi unggulan pariwisata. Untuk itu kerjasama ekonomi dengan investor sangatlah diperlukan.

\section{e. Menurunnya nilai-nilai budaya}

Dengan adanya pengaruh globalisasi yang telah memasuki wilayah tradisional masyarakat sampai ke pedesaan, nilai-nilai budaya masyarakat yang sebelumnya dijunjung tinggi secara perlahan nilainya mulai menurun. Di sisi lain penurunan nilai-nilai budaya tersebut menimbulkan adanya sikap komersial masyarakat.

Dari kedua faktor internal dan eksternal yang dijabarkan dalam kekuatan, kelemahan, peluang, serta hambatan tersebut, diperoleh strategi yang dikenal dengan strategi SWOT, yang terdiri dari strategi SO, strategi WO, strategi ST, dan strategi WT yang dipergunakan untuk 
menganalisis strategi pengembangan kawasan Taman Prasejarah Leang-leang.

\section{Strategi SO}

Strategi SO merupakan strategi yang menggunakan kekuatan-kekuatan untuk memanfaatkan peluang yang ada. Strategi SO dalam pengembangan lokasi wisata dirumuskan dengan menggunakan berbagai kekuatan yang ada.

\section{a. Sumber Daya Manusia}

Memanfaatkan SDM yang ada serta kesiapan masyarakat dalam mendukung pembangunan pariwisata di wilayah kawasan Taman Prasejarah Leang-leang.

\section{b. Promosi}

Promosi mengenai Taman Prasejarah Leang-leang dengan segala potensi dan keunikannya perlu dilakukan secara terus menerus. Promosi ini dapat dilakukan dengan mengadakan even-even wisata disamping promosi melalui Biro Perjalanan Wisata dan brosur-brosur yang memuat tentang informasi secara lengkap.

\section{c. Kerjasama}

Peningkatan kerjasama, koordinasisinkronisasi serta keterpaduan antar lembaga terkait, pengusaha dan masyrakat dalam memanfaatkan potensi wisata Taman Prasejarah Leang-leang.

\section{d. Kemudahan}

Pemberian kemudahan bagi investor agar berminat menanamkan modalnya di daerah kawasan Taman Prasejarah Leangleang.

\section{e. Peningkatan Daya Tarik}

Daya tarik wisata budaya Taman Prasejarah Leang-leang memiliki nilai-nilai komersial yang akan mampu menarik minat wisatawan untuk datang berkunjung, namun demikian harus ada jaminan bahwa waktu dan biaya yang telah mereka keluarkan senilai dengan pengalaman yang diperoleh setelah mengunjungi objek tersebut.

\section{Strategi WO}

Strategi WO dalam pengembangan objek wisata budaya Taman Prasejarah Leang-leang merupakan strategi yang meminimalkan kelemahan untuk memanfaatkan peluang. Strategi WO dalam pengembangan wilayah tempat wisata ke depan dapat dijabarkan sebagai berikut.

\section{Promosi}

Meningkatkan penyelenggaraan promosi mengenai Taman Prasejarah Leang-leang dengan segala potensi dan keunikannya. Promosi ini dapat dilakukan secara terus menerus dengan mengadakan even-even wisata, disamping promosi melalui Biro Perjalanan Wisata dan brosurbrosur di berbagai media massa cetak maupun elektronik yang diharapkan dapat meningkatkan jumlah kunjungan wisatawan baik nusantara maupun mancanegara.

\section{a. Penanaman Modal}

Mengajak masyarakat yang memiliki modal untuk mau menanamkan modalnya pada sektor pariwisata khususnya dalam penggarapan berbagai potensi yang ada, untuk tujuan pengembangan pariwisata.

\section{b. Penciptaan Image \\ Membentuk image bahwa objek} wisata budaya ini sebagai salah satu daya tarik wisata budaya yang unik dengan cara memasyarakatkan pariwisata, sekaligus mempariwisatakan masyarakat sekitar. Hal ini dapat dilakukan secara terus menerus mengajak masyarakat untuk berperan aktif dalam menggalakkan pariwisata di daerah ini, dengan memanfaatkan aktivitas sosial masyarakat untuk tujuan pariwisata, mengadakan berbagai pertunjukkan kesenian yang diadakan secara rutin, 
sehingga wisatawan akan tertarik untuk menyaksikan-nya.

\section{c. Kerjasama}

Meningkatkan kerjasama dengan stake holders, pemangku kepentingan, yang berkompeten dengan pariwisata seperti, Biro Perjalanan Wisata, organisasiorganisasi pariwisata, serta dengan Pemerintah Pusat dan Pemerintah Kabupaten Maros. Hubungan kerjasama ini, diharapkan semua pihak memahami dan bertanggung jawab atas pengembangan pariwisata di wilayah ini.

\section{d. Amenitas}

Menyediakan dan mengembangkan berbagai amenitas (sarana penunjang) pariwisata yang dapat memberikan kenyamanan kepada wisatawan. Beberapa sarana yang disediakan dalam rangka meningkatkan kepuasan wisatawan, antara lain warung makan, toko cinderamata, pertunjukkan seni tradisional, dan homestay.

\section{Strategi ST}

Strategi ST merupakan strategi yang menggunakan kekuatan untuk mengatasi berbagai hambatan yang ada. Strategi dalam pengembangan objek wisata budaya Taman Prasejarah Leang-leang ke depan dapat dirumuskan dengan memanfaatkan berbagai kekuatan yang ada dalam menjawab berbagai hambatan/tantangan yang dihadapi. Adapun strategi dimaksud adalah sebagai berikut :

\section{a. Sadar Wisata}

Membentuk Kelompok Sadar Wisata dengan menanamkan prinsip-prinsip Sapta Pesona yang terdiri atas aman, tertib, bersih, sejuk, indah, ramah tamah, dan kenangan. Adapun tujuannya agar dapat mendukung program pembangunan pariwisata. Kelompok sadar wisata ini bertugas antara lain, memberikan penyuluhan, pengarahan dan penjelasan kepada masyarakat, khususnya yang bertempat tinggal di sekitar objek wisata, tentang manfaat pembangunan pariwisata bagi upaya menunjang pembangunan perekonomian daerah serta meningkatkan kesejahteraan masyarakat.

\section{b. Partisipasi Masyarakat}

Peningkatan peran masyarakat, jika masyarakat lokal dilibatkan sejak awal dan diberi kesempatan untuk menyampaikan aspirasinya, maka mereka akan membantu upaya pengembangan pariwisata, dan pada akhirnya akan dengan sukarela mendukung kegiatan-kegiatan pariwisata, seperti membagi informasi tentang pariwisata di daerahnya. Dari sini diharapkan akan muncul rasa memiliki dan tanggung jawab dalam diri masyarakat terhadap pengembangan pariwisata, karena secara tidak langsung upaya pengembangan pariwisata akan berdampak pula pada peningkatan kesejah-teraan masyarakat sekitar, oleh karena itu masyarakat lokal perlu dilibatkan partisipasinya, seperti menjaga kebersihan, keamanan dan pelestarian situs objek wisata.

\section{c. Penawaran Potensi}

Menawarkan berbagai potensi yang ada kepada pihak luar, baik kepada pihak pemerintah maupun pihak swasta untuk menggarap berbagai potensi yang ada dalam rangka pengembangan pariwisata di daerah tersebut.

\section{Strategi WT}

Strategi WT merupakan strategi yang meminimalkan kelemahan-kelemahan dan untuk menghindari hambatan-hambatan. Strategi WT dalam pengembangan wilayah tempat wisata di masa yang akan datang akan dapat dilakukan strategi berikut. 


\section{a. Program}

Penyusunan program dan kegiatan yang berbasis masyarakat dalam rangka mendorong tumbuhnya peran serta masyarakat di bidang pariwisata. Penyusunan program ini hendaknya dibuat atas inisiatif berdasarkan kebutuhan masyarakat sendiri.

\section{b. Pariwisata adalah sistem}

Menyadari pariwisata adalah sebuah sistem yang melibatkan semua pihak (stake holder) serta komponen masyarakat yang ada. Jika hal ini telah disadari maka pengembangan pariwisata di daerah ini perlu direduksi, diarahkan, dengan melibatkan semua pihak, baik masyarakat, pihak pemerintah, dan pihak swasta.

\section{c. Studi Banding}

Mengadakan kunjungan komparatif pada daerah-daerah yang memiliki karakteristik potensi sejenis dan lebih awal berkembang. Salah satu tujuan studi banding ini adalah untuk memperoleh pemahahan mendalam apa yang harus dilakukan dan sebaliknya apa yang harus dihindari.

\section{KESIMPULAN, KETERBATASAN DAN REKOMENDASI}

\section{Kesimpulan}

Dengan memahami berbagai faktor kondisi baik potensi, kekuatan dan peluang, serta ancaman dalam pengembangan wisata budaya Taman Prasejarah Leang-leang maka dapat disimpulkan.

1. Taman Prasejarah Leang-leang memiliki potensi-potensi kuat untuk dikembangkan sebagai destinasi wisata, karena memiliki empat nilai penting yaitu nilai penting sejarah, nilai penting pengetahuan, nilai penting kebudayaan, dan nilai penting kepariwisataan.
2. Memandang penting peningkatan pengembangan destinasi wisata budaya Taman Prasejarah Leangleang sebagai destinasi utama di kawasan Indonesia Timur pada umumnya dan Provinsi Sulawesi Selatan pada khususnya.

3. Peningkatkan potensi dan kualitas produk wisata, dengan penekanan nilai-nilai edukatif kultural disamping rekreatif yang menghibur.

4. Daya tarik wisata budaya Taman Prasejarah Leang-leang, memiliki nilai-nilai komersial yang mampu menarik minat wisatawan berdatangan dengan jaminan, bahwa waktu dan biaya yang telah dikeluarkan seimbang dengan pengalaman yang diperoleh setelah mengunjungi objek tersebut.

5. Sebagai kawasan yang relatif baru dikembangkan, Taman Prasejarah Leang-leang memiliki perpaduan potensi alam, dan budaya budaya yang terbuka untuk dikembangkan sebagai ekowisata.

\section{Keterbatasan}

Belum banyak kajian-kajian yang mengupas pariwisata di Taman Prasejarah Leang-leang, penelitian yang dilakukan selama ini adalah penelitian-penelitian dari segi arkeologi dan geologi. Pemerintah pusat, pemerintah kabupaten, dan masyarakat sangat terbatas sumber daya manusianya untuk menggali potensi wisatanya dan mengelola Taman Prasejarah Leang-leang agar menjadi destinasi wisata utama di Wilayah Indonesia Timur.

\section{Rekomendasi}

Sebagai implikasi dari kesimpulan diatas, maka perlu direkomendasikan beberapa hal untuk ditindaklanjuti. 


\begin{abstract}
Pertama, dalam upaya pengembangan kepariwisataan yang sekarang sedang digalakkan harus berwawasan pelestarian. Hal ini penting dikemukakan guna menghindari distorsi nilai penting warisan budaya sebagai sumber informasi masa lampau, artinya jangan sampai terjadi keberhasilan kepariwisataan justru akan menghancurkan substansi aset itu sendiri.
\end{abstract}

Kedua, sejalan dengan semangat Pemerintah Pusat maupun daerah mengembangkan pariwisata untuk kesejahteraan masyarakat, maka diperlukan pula pembangunan non fisik yang menyangkut mental spiritual masyarakat di sekitar situs Taman Prasejarah Leang-leang. Hal ini perlu dilakukan untuk mengimbangi pembangunan fisik sebagai konsekuensi pengembangan kepariwisataaan.

Ketiga, dipandang penting untuk melakukan penelitian lanjutan khususnya masalah peningkatan potensi dan produk wisata. Peningkatan potensi dan produk wisata disini diharapkan mampu mendukung keberadaan Taman Prasejarah Leang-leang sebagai destinasi utama Indonesia Timur serta dapat mencapai tujuan pariwisata yakni untuk kesejahteraan masyarakat.

\section{REFERENSI}

Anonim. Undang-Undang Republik Indonesia Nomor 10 Tahun 2009, Tentang Kepariwisataan. Jakarta: Sekretariat Negara Republik Indonesia.

Anonim. Undang-Undang Republik Indonesia Nomor 11 Tahun 2010, Tentang Cagar Budaya. Jakarta: Sekretariat Negara Republik Indonesia.

Aubert, M., A. Brumm, M. Ramli, T.
Sutikna, E. W. Saptomo, B. Hakim, M. J. Morwood, G. D. van den Bergh, L. Kinsley, and A. Dosseto. 2014. Pleistocene Cave Art from Sulawesi, Indonesia. Nature 514 (7521): 223-27. doi:10.1038/Nature 13422.

Balai Pelestarian Peninggalan Sejarah dan Purbakala. 2011. Zonasi Gua-Gua Prasejarah Kabupaten Pangkep 2011. Makassar: Balai Pelestarian Peninggalan Purbakala

Budi Hermawan. 2012. Analisis Kontribusi Transaksi Pariwisata terhadap Produk Domestik Bruto Sektor Pariwisata. Media Wisata. 7(1):1129.

Budi Sulistyanto. 2008. Resolusi Konflik Dalam Managemen Warisan Budaya Situs Sangiran. Disertasi, Jakarta: Fakultas Ilmu Pengetahuan Budaya, Program Studi Arkeologi, Universitas Indonesia.

Fadlan Intan.2012. Pemetaan Potensi Situssitus Gua di Kawasan Karst MarosPangkep, Sulawesi Selatan: Kajian Arkeologi Publik. Laporan Penelitian Arkeologi. Jakarta: Pusat Penelitian Arkeologi Nasional Kementerian Pendidikan dan Kebudayaan.

Haniek Listyorini dan Nina Mistriani. 2015. Strategi Pengembangan Desa Wisata Berbasis Budaya dan Ekonomi Serta Dampaknya Terhadap Ekonomi Masyarakat di Desa Wisata Loram Kulon Kabupaten Kudus. Laporan Penelitian, Semarang: Lembaga Penelitian dan Pengabdian Kepada Masyarakat (LPPM) STIEPARI

Ismayanti, 2010. Pengantar Pariwisata. Jakarta: Gramedia Widiasarana Indonesia.. 
Muhammad Nur, 2009. Pelestarian Kompleks Gua Leang-Leang, Kabupaten Maros, Sulawesi Selatan. Tesis. Yogyakarta: Program Pasca Sarjana Universitas Gadjah Mada.

Oka A. Yoeti 2008. Perencanaan dan Pengembangan Pariwisata. Jakarta: Pradnya Paramita.

Siagian, Sondang P. 2008. Manajemen Stratejik. Jakarta: Bumi Aksara.

Sugiyono. 2012. Metode Penelitian Kualitatatif. Bandung: Alfabeta.

Teguh F dan Avenzora R. 2013. Ekowisata dan Pembangunan Pariwisata Berkelanjutan di Indonesia, Potensi, Pembelajaran, dan Kesuksesan. Jakarta: Kementerian Pariwisata dan Ekonomi Kreatif.

Winardi, J. 2013. Manajemen Perubahan (Management of Change). Jakarta: Kencana Prenada Media Group. 